\title{
Zonula Occludens Toxin Modulates Tight Junctions through Protein Kinase C- dependent Actin Reorganization, In Vitro
}

\author{
Alessio Fasano, ${ }^{\star}$ Carla Fiorentini," Gianfranco Donelli," Sergio Uzzau, ${ }^{*}$ James B. Kaper, ${ }^{\ddagger}$ Klara Margaretten, ${ }^{\ddagger}$ \\ Xueda Ding, ${ }^{\boldsymbol{\$}}$ Stefano Guandalini, ${ }^{9}$ Laurie Comstock, ${ }^{\ddagger}$ and Simeon E. Goldblum ${ }^{\$}$ \\ ${ }^{*}$ Division of Pediatric Gastroenterology and Nutrition, ${ }^{\ddagger}$ Center for Vaccine Development, and ${ }^{\S}$ Division of Infectious Disease, \\ Department of Veterans Affairs Medical Center, University of Maryland School of Medicine, Baltimore, Maryland 21201; "Department \\ of Ultrastructures, Istituto Superiore Sanitá 00161 Rome, Italy; and 'Division of Pediatrics, University of Catanzaro, 88100 Catanzaro, \\ Italy
}

\begin{abstract}
The intracellular signaling involved in the mechanism of action of zonula occludens toxin (ZOT) was studied using several in vitro and ex vivo models. ZOT showed a selective effect among various cell lines tested, suggesting that it may interact with a specific receptor, whose surface expression on various cells differs. When tested in IEC6 cell monolayers, ZOT-containing supernatants induced a redistribution of the F-actin cytoskeleton. Similar results were obtained with rabbit ileal mucosa, where the reorganization of F-actin paralleled the increase in tissue permeability. In endothelial cells, the cytoskeletal rearrangement involved a decrease of the soluble G-actin pool $(-27 \%)$ and a reciprocal increase in the filamentous F-actin pool $(+22 \%)$. This actin polymerization was time- and dose-dependent, and was reversible. Pretreatment with a specific protein kinase C inhibitor, CGP41251, completely abolished the ZOT effects on both tissue permeability and actin polymerization. In IEC6 cells ZOT induced a peak increment of the PKC$\alpha$ isoform after $3 \mathrm{~min}$ incubation. Taken together, these results suggest that ZOT activates a complex intracellular cascade of events that regulate tight junction permeability, probably mimicking the effect of physiologic modulator(s) of epithelial barrier function. (J. Clin. Invest. 1995. 96:710720.) Key words: cholera $\bullet$ diarrhea $\cdot$ cytoskeleton $\cdot$ intestine - permeability
\end{abstract}

\section{Introduction}

Most Vibrio cholerae vaccine candidates that are constructed by deleting $c t x$ gene sequences encoding cholera toxin still

Portions of this work were presented at the 89th American Gastroenterology Association Meeting in New Orleans, LA on 17 May 1994.

Address correspondence to Alessio Fasano, Division of Pediatric Gastroenterology and Nutrition, Department of Pediatrics, University of Maryland School of Medicine, 22 Greene Street Box 140, Baltimore, MD 21201. Phone: 410-328-0812; FAX: 410-328-1072; E-mail:afasano@umabnet.ab.umd.edu.

Received for publication 14 September 1994 and accepted in revised form 20 April 1995.

1. Abbreviations used in this paper: $\mathrm{CD}$, Clostridium difficile; $\mathrm{I}_{\mathrm{sc}}$, shortcircuit current; PKC, protein kinase $\mathrm{C}$; Rt, tissue resistance, tj, tight junctions; TPA, 12-tetradecanoylphorbol-13-acetate; ZOT, zonula occludens toxin.

The Journal of Clinical Investigation, Inc.

Volume 96, August 1995, 710-720 cause mild diarrhea in more than one-half of the vaccinees (1). We have identified a second toxin, named ZOT $^{1}$ for zonula occludens toxin, that may contribute to the residual diarrhea (2). When tested on rabbit ileal mucosa, this toxin increases the intestinal permeability by altering the structure of intercellular tight junctions $(\mathrm{t} j)$. We hypothesized that as a consequence of modification of the paracellular pathway, the intestinal mucosa becomes more permeable, and water and electrolytes, under force of hydrostatic pressure, leak into the lumen resulting in diarrhea. The zot gene is located immediately adjacent to the $c t x$ genes and the high percent concurrence of the zot gene with the $c t x$ genes among $V$. cholerae strains $(3,4)$ suggests a possible synergistic role of ZOT in the causation of acute dehydrating diarrhea typical of cholera. Recently, zot gene has also been identified in other enteric pathogens (5).

The t $\mathrm{j}$ or zonula occludens is one of the hallmarks of absorptive and secretory epithelia $(6,7)$. As a barrier between apical and basolateral compartments, it selectively regulates the passive diffusion of ions and small water-soluble solutes through the paracellular pathway (8). This barrier maintains any gradient generated by the activity of pathways associated with the transcellular route (9). The observation that in rabbit small intestine, ZOT ( $a$ ) does not affect $\mathrm{Na}^{+}$-glucose coupled active transport; $(b)$ is not cytotoxic; $(c)$ fails to completely abolish the transepithelial resistance; and, most importantly, $(d)$ induces a reversible increase of tissue permeability (2), makes this moiety a potential tool for studying intestinal tj regulation. In recent years much has been discovered about the structure, function, and regulation of $\mathrm{tj}(8,10,11)$. However, the precise mechanism(s) through which they operate are still incompletely understood. The present study focuses on ZOT's mechanism of action. We have demonstrated that ZOT reversibly activates a cascade of intracellular events that lead to increased intestinal permeability. We propose that these mechanisms are operative in the physiologic regulation of the intestinal tj.

\section{Methods}

\section{Bacterial strains and growth conditions}

The bacterial strains used in this paper are described in Table I. $V$. cholerae 395 (classical Ogawa) and E7946 (El Tor Inaba) are cholera toxin-positive strains that have been extensively studied in volunteers (12). CVD 110 is a $V$. cholerae strain (El Tor biotype) deleted of $c t x \mathrm{~A}$, zot, and ace genes (13). This last strain was used as a host for plasmid pZ14, a zot-containing plasmid constructed by digesting pBB241 (14) with Hind III. The resulting 5' overhang was filled in with Klenow fragment and the linearized plasmid was then digested with Xbal yielding a zot fragment of $1.5 \mathrm{~kb}$. This fragment was cloned into the vector pTTQ181 (Amersham Corp., Arlington Heights, IL) 
Table I. Description of Bacterial Strains

\begin{tabular}{|c|c|c|c|c|}
\hline Strain & Description & Phenotype & Effect on intestinal permeability & Reference \\
\hline E7946 & V. cholerae biotype El Tor & $\mathrm{CT}+/ \mathrm{ZOT}+/$ Ace + & Yes & 12 \\
\hline 395 & V. cholerae biotype Classical & $\mathrm{CT}+/ \mathrm{ZOT}+/$ Ace + & Yes & 12 \\
\hline CVD110 & V. cholerae vaccine candidate derived from E7946 & CT-/ZOT-/Ace- & No & 13 \\
\hline pTTQ181 & CVD110 + plasmid pTTQ181 & CT-/ZOT-/Ace- & No & this paper \\
\hline $\mathrm{pZ14}$ & CVD110 + plasmid pTTQ181 containing zot gene & $\mathrm{CT}-/ \mathrm{ZOT}+/$ Ace - & Yes & this paper \\
\hline
\end{tabular}

which has been modified by interruption of the $\mathrm{Ap}^{\mathrm{R}}$ gene with a $\mathrm{Km}^{\mathrm{R}}$ cassette. pTTQ181 was digested with EcoRI, filled in, and then digested with Xba I. The zot fragment ligated into this vector in the correct orientation was named pZ14. The same recipient (CVD110) containing the plasmid vector used to clone zot (pTTQ181) was used as a negative control. pZ14 and pTTQ181 are then isogenic plamids that differ only for the presence of a DNA fragment containing zot gene in pZ14. Culture supernatants were prepared by centrifugation of overnight cultures $\left(37^{\circ} \mathrm{C}\right.$, Luria Bertani (LB) broth containing $50 \mu \mathrm{g} / \mathrm{ml}$ kanamycin) passed through a $0.45-\mu \mathrm{m}$ filter (Millipore Corp., Milford, MA). For the inducible clones, overnight cultures of pZ14 and pTTQ181 were diluted to obtain an initial absorbance at $600 \mathrm{nM}$ of $0.4-0.5$. $2 \mathrm{mM}$ isopropyl-thio- $\beta$-D-Galactopyranoside (IPTG) ( 5 Prime-3 Prime, Inc., Boulder, CO) was then added to the cultures which were incubated for an additional $2 \mathrm{~h}$. All cultures were then subjected to ultrafiltration through Centricon filters (Vangard International Inc., Neptune, NJ) with a $10-\mathrm{kD} M_{\mathrm{r}}$ cut-off size. Culture fractions $>10 \mathrm{kD}$ were washed twice with PBS, reconstituted to the original volume in PBS, and tested for activity.

\section{Cell cultures}

HT29cl. 19A. The human colon carcinoma cell line HT29cl. 19A (15) was grown in cell-culture flasks (Falcon Labware, Oxnard, CA) under humidified atmosphere of air/ $\mathrm{CO}_{2}(19: 1)$ at $37^{\circ} \mathrm{C}$ in DME containing $10 \%$ (vol/vol) fcs, $40 \mathrm{mg}$ of penicillin/liter and $90 \mathrm{mg}$ of streptomycin/ liter. Cells were subcultured at a surface ratio of 1:5 after trypsin treatment every $5 \mathrm{~d}$, when they had reached $70-80 \%$ confluence. The passage number of the cells used in this study varied between 15 and 30 .

IEC6 cells. IEC6 cells derived from crypt cells of germ-free rat small intestine (16) were grown in cell-culture flasks (Falcon Labware) at $37^{\circ} \mathrm{C}$ in an atmosphere of $95 \%$ air and $5 \% \mathrm{CO}_{2}$. The complete medium consisted of DME with 4.5 grams/liter glucose, containing 5\% FBS (irradiated), $10 \mu \mathrm{g} / \mathrm{ml}$ insulin, $4 \mathrm{mM}$ L-glutamine, $50 \mathrm{U} / \mathrm{ml}$ penicillin, and $50 \mu \mathrm{g} / \mathrm{ml}$ streptomycin. The passage number of the cells used in this paper varied between 15 and 20 .

$L L C P K_{I}$ cells. Pig kidney cortex cells (17) were grown in cellculture flasks (Falcon Labware) at $37^{\circ} \mathrm{C}$ in an atmosphere of $95 \%$ air $5 \% \mathrm{CO}_{2}$. The culture medium consisted of DME supplemented with $10 \%$ FBS. Cells ranging from passage 185 to 200 were passed weekly by trypsinizing $(0.25 \%$ trypsin, $0.02 \%$ EDTA) $70-80 \%$ confluent monolayers.

Endothelial cells. Bovine pulmonary artery endothelial cells (18) were obtained from American Type Culture Collection (Rockville, MD). Cells were grown at $37^{\circ} \mathrm{C}$ under $5 \% \mathrm{CO}_{2}$ in $\mathrm{DME}$ enriched with $20 \%$ heat-inactivated $\left(56^{\circ} \mathrm{C}, 30 \mathrm{~min}\right.$ ) FCS (HyClone Laboratories, Logan, UT), $4 \mathrm{mM}$ L-glutamine, nonessential amino acids, and vitamins in the presence of penicillin $(50 \mathrm{U} / \mathrm{ml})$ and streptomycin $(50 \mu \mathrm{g} / \mathrm{ml})$. Cultures were determined to be endothelial by uniform morphology and by quantitative determination of angiotensin-converting enzyme activity with commercially available ${ }^{3} \mathrm{H}$-benzoyl-Phe-Ala-Pro substrate (Ventrex Laboratories, Inc., Portland, ME). Only cell passages 3-7 were studied.

\section{Ussing chambers}

Experiments were carried out as previously described (2). Briefly, adult male New Zealand white rabbits $(2-3 \mathrm{~kg}$ ) were killed by cervical dislocation. A $20-\mathrm{cm}$ segment of ileum was removed, rinsed free of the intestinal content, opened along the mesenteric border, and stripped of muscular and serosal layers. Eight sheets of mucosa so prepared were then mounted in lucite Ussing chambers $\left(1.12 \mathrm{~cm}^{2}\right.$ opening $)$, connected to a voltage clamp apparatus (EVC 4000; World Precision Instruments, Saratosa, FL), and bathed with freshly prepared buffer containing (mM): $\mathrm{NaCl}, 53 ; \mathrm{KCl}, 5 ; \mathrm{Na}_{2} \mathrm{SO}_{4}, 30.5 ;$ mannitol, 30.5; $\mathrm{Na}_{2} \mathrm{HPO}_{4}, 1.69$; $\mathrm{NaH}_{2} \mathrm{PO}_{4}, 0.3 ; \mathrm{CaCl}_{2} 1.25 ; \mathrm{MgCl}_{2} 1.1 ; \mathrm{NaHCO}_{3}, 25$. The bathing solution was maintained at $37^{\circ} \mathrm{C}$ with water-jacketed reservoirs connected to a constant temperature circulating pump and gassed with $95 \% \mathrm{O}_{2}$ and $5 \% \mathrm{CO}_{2}$. Potential difference (PD) was measured and short-circuit current $\left(I_{s c}\right)$ and tissue resistance $(R t)$ were calculated as previously described (2). $300 \mu \mathrm{l}$ of culture supernatant was added to the mucosal side; $300 \mu 1$ of the same sample was also added to the serosal side to preserve the osmotic balance. Variation of $P D, I_{s c}$, and $R t$ were then recorded every $10 \mathrm{~min}$. Because of tissue variability, data are presented as $\Delta \mathrm{Rt}$ (Rt at time $x)-(\mathrm{Rt}$ at time 0$)$. At the end of every experiment, $0.5 \mathrm{mM}$ glucose was added to the mucosal side of each chamber. Only those tissues which showed an increase in $I_{s c}$ in response to glucose (indicating tissue viability) were included in the analysis. In some experiments, tissues were preexposed to either $100 \mathrm{mM}$ neomycin sulphate (Sigma Chemical Co., St. Louis, MO) $10 \mathrm{nM}$ staurosporine (Sigma Chemical Co.), $10^{-8}$ M 12-tetradecanoylphorbol-13-acetate (TPA), 10 nM CGP41251, or $10 \mathrm{nM}$ CGP42700 $10 \mathrm{~min}$ before and throughout the pZ14 supernatant exposure.

In the experiments performed with HT29cl. 19A monolayers, cells were grown to confluence (12-14 d after plating at a 1:2.5 surface ratio) on tissue culture-treated polycarbonate filters firmly attached to a polystyrene ring (6.4 mm diameter, transwell; Costar Corp., Cambridge, MA). The filter was placed in a tightly fitting insert separating the serosal and mucosal compartment of a modified Ussing chamber and the experiments were carried out as described above for the rabbit intestine.

\section{Fluorescence microscopy}

IEC6 and $L L C P K_{1}$ cells. After incubation with culture supernatants, cells $\left(2 \times 10^{4}\right.$ cells $\left./ \mathrm{ml}\right)$ cultured on coverslips were fixed in $3.7 \%$ formaldehyde in PBS ( $\mathrm{pH} \mathrm{7.4)} \mathrm{for} 10 \mathrm{~min}$ at room temperature. After washing in the same buffer, the cells were permeabilized with $0.5 \%$ Triton X-100 (Sigma Chemical Co.) in phosphate buffer ( $\mathrm{pH} \mathrm{7.4)} \mathrm{for} 10$ $\mathrm{min}$ at room temperature. The cells were then incubated with fluoresceinphalloidin (Sigma Chemical Co.) at $37^{\circ} \mathrm{C}$ for $30 \mathrm{~min}$. Finally, the cells were washed with PBS, the coverslips were mounted with glycerol-PBS (1:1) at $\mathrm{pH} 8.0$, and 200 cells for each condition were analyzed in triplicate in blind fashion with a fluorescence microscope (Optiphot; Nikon Inc., Melville, NY). The results were expressed in percentage of cells showing cytoskeleton rearrangement as defined in Fig. $2 \mathrm{~A}$. In some experiments, IEC6 cells were pretreated with either $10 \mathrm{nM}$ CGP41251 or $10 \mathrm{nM}$ CGP42700 $30 \mathrm{~min}$ before and throughout the pZ14 supernatant exposure. 
Rabbit small intestine. Rabbit small intestine was prepared as described above, mounted in Ussing chambers, and exposed to either pZ14 $(\mathrm{ZOT}+)$ or pTTQ181 (ZOT-) supernatants. Once maximal changes in tissue resistances were obtained in tissues exposed to pZ14 supernatant, the intestinal samples were immediately removed, fixed, frozen, sliced, and subsequently subjected to the same treatment and analysis described above for the IEC6 cells.

\section{Scanning electron microscopy}

For scanning electron microscopy studies, IEC6 cells were seeded onto 13-mm diameter glass coverslips inserted in the wells of a 24-well plate $\left(5 \times 10^{4}\right.$ cells/well $)$. After 24 -h exposure to either ZOT-containing supernatant or negative control, the cells were fixed with $2.5 \%$ glutaraldehyde in $0.1 \mathrm{M}$ cacodylate buffer ( $\mathrm{pH} \mathrm{7.4)}$ ) for $20 \mathrm{~min}$ at room temperature. After postfixation in $1 \% \mathrm{OsO}_{4}$ for $30 \mathrm{~min}$, cells were dehydrated through graded ethanols, critical point dried under $\mathrm{CO}_{2}$, and gold coated by sputtering. The samples were examined with a scanning electron microscope (Cambridge Research \& Instruments, Cambridge, MA).

\section{Total protein concentrations in endothelial cell monolayers}

Methodologies for determining F- and G-actin pools involve fixation, permeabilization, and extraction procedures which preclude protein determinations on the same monolayers. Therefore, additional simultaneously plated cells for total protein determination were cultured under identical condition as the monolayers to be assayed for the F- and Gactin pools. Postconfluent monolayers in the wells of 6-well plates were washed twice with PBS and gently detached with a brief (1-2 min) trypsin $(0.5 \mathrm{mg} / \mathrm{ml})$ exposure with gentle agitation, followed immediately by neutralization with FBS-containing medium. The cells were centrifuged $(600 \mathrm{~g}, 10 \mathrm{~min})$, again washed twice in PBS, and lysed in lysing buffer (3\% SDS, 1 mM DTT, 1, $10 \mu$ M PMSF, 1 mM EDTA, $50 \mathrm{mM}$ Tris- $\mathrm{HCl}, \mathrm{pH} \mathrm{8.0)}$. Lysates were assayed for protein concentration with the standard Bio-Rad DC Protein Assay (Bio-Rad Chemical Division, Richmond, CA). Total endothelial protein was used to standardize F- and G-actin measurements.

\section{$F$-actin quantitation by spectrofluorometry}

Endothelial F-actin was fluorometrically measured as previously described (18). Endothelial cells $\left(5.8 \times 10^{5}\right.$ cells in $2 \mathrm{ml}$ media) were seeded into the wells of 6-well plates and cultured for $72 \mathrm{~h}\left(37^{\circ} \mathrm{C}\right.$, $5 \% \mathrm{CO}_{2}$ ). The monolayers were exposed to either pZ14 or pTTQ181 supernatant for $24 \mathrm{~h}$ after which they were washed twice in a buffer ( $75 \mathrm{mM} \mathrm{KCl}, 3 \mathrm{mM} \mathrm{MgSO}$, $1 \mathrm{mM}$ EGTA, $10 \mathrm{mM}$ imidazole, 0.2 $\mathrm{mM}$ DTT, $10 \mu \mathrm{g} / \mathrm{ml}$ aprotinin, $0.1 \mathrm{mM}$ PMSF) and fixed with $3.7 \%$ formaldehyde for $15 \mathrm{~min}$. Monolayers were permeabilized ( $0.2 \%$ Triton X-100 in buffer, $5 \mathrm{~min})$, stained with NBD-phallicidin $\left(1.65 \times 10^{-7}\right.$ $\mathrm{M}, 20 \mathrm{~min}$ ), and extracted with ice-cold methanol (overnight, $-20^{\circ} \mathrm{C}$ ). Staining and extractions were performed in the dark. Extracts were harvested into cuvettes and intraendothelial fluorescence was measured in a luminescence spectometer (LS30; Perkin-Elmer Corp., Norwalk, CT) at room temperature at $465 \mathrm{~nm}$ excitation (10-nm slit) and 535 $\mathrm{nm}$ emission (10-nm slit) and expressed in arbitrary fluorescent units per milligram total endothelial cell protein. Application of NBD-phallicidin to fixed permeabilized endothelial monolayers resulted in $78.8 \%$ penetration of the probe into the cell and $99.98 \%$ of intracellular probe was extracted with a single methanol treatment as measured by fluorometry. In other experiments, monolayers were pretreated with either $10 \mathrm{nM}$ CGP41251 or $10 \mathrm{nM}$ CGP42700 $30 \mathrm{~min}$ before and throughout the pZ14 supernatant exposure.

\section{DNase 1 inhibition assay}

Endothelial G-actin was measured using the DNase 1 inhibition assay as previously described (18). DNase 1 obtained from bovine pancreas (Sigma Chemical Co.) was dissolved at $10 \mathrm{mg}$ protein $/ \mathrm{ml}$ in $0.125 \mathrm{M}$ Tris- $\mathrm{HCl}$ (pH 7.5) $5 \mathrm{mM} \mathrm{MgCl}_{2}, 2 \mathrm{mM} \mathrm{CaCl}_{2}, 1 \mathrm{mM} \mathrm{NaN}_{3}$, and 0.1 mM PMSF to increase its stability. The stock solution was then diluted
100 times with $20 \mathrm{mM}$ imidazole, $\mathrm{pH} 7.5,30 \mathrm{mM} \mathrm{NaCl}_{2}$, and $15 \%$ glycerol. The enzyme was freshly made every $2 \mathrm{~h}$ and kept on ice. Calf thymus DNA (type 1; Sigma Chemical Co.) was used as substrate for the DNase 1. The fibrous DNA preparation was cut into fine pieces and suspended in $0.1 \mathrm{M}$ Tris- $\mathrm{HCl}$ ( $\mathrm{pH} 7.5$ ), $4 \mathrm{mM} \mathrm{MgSO}_{4}, 1.8 \mathrm{mM} \mathrm{CaCl}_{2}$ at a concentration of $80 \mu \mathrm{g} \mathrm{DNA} / \mathrm{ml}$. The DNA was brought into solution by slow stirring at $4^{\circ} \mathrm{C}$ for $48 \mathrm{~h}$ after which the solution was sequentially passed through 0.45 - and $0.22-\mu \mathrm{m}$ pore size filters and stored at $4{ }^{\circ} \mathrm{C}$. The absorbance of the final substrate at $260 \mathrm{~nm}$ varied between 1.05 and 1.15. The DNase 1 was mixed with DNA substrate in the cuvette of a Gilford response spectrophotometer (Ciba Corning Diagnostics, Oberlin, $\mathrm{OH}$ ) and the slope of the linear portion of the $\triangle \mathrm{A} 260$ recorded. Purified bovine skeletal muscle actin (Sigma Chemi-

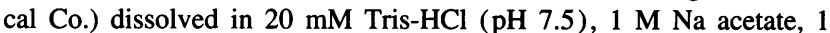
$\mathrm{mM} \mathrm{CaCl}, 1 \mathrm{mM}$ ATP, $0.75 \mathrm{M}$ guanidine $\mathrm{HCl}$ was used as the Gactin standard to calibrate the assay. Endothelial monolayers grown in 6-well plates were exposed to the pZ14 and pTTQ181 supernatants. The monolayers were washed with Dulbecco's PBS (without $\mathrm{Ca}^{2+}$ and $\mathrm{Mg}^{2+}$ ) and permeabilized with lysing buffer (HBSS with $1 \%$ Triton X$100,2 \mathrm{mM} \mathrm{MgCl}$, 2 mM EGTA, $0.2 \mathrm{mM}$ ATP, $0.5 \mathrm{mM}$ DTT, $0.1 \mathrm{mM}$ PMSF) $0.5 \mathrm{ml} /$ well for $5 \mathrm{~min}$. The G-actin-containing supernatants were then tested in the DNase 1 inhibition assay to generate inhibitory activities that fell on the linear portion of the standard curve (i.e., 30$70 \%$ inhibition). The inhibitory activities were interpolated to G-actin concentrations which were used to calculate G-actin expressed in microgram per milligram total endothelial cell protein. In selected experiments, monolayers were preincubated with either $10 \mathrm{nM} \mathrm{CGP41251}$ or $10 \mathrm{nM}$ CGP42700 $30 \mathrm{~min}$ before and throughout the pZ14 or pTTQ181 supernatant exposure.

\section{Protein kinase $C(P K C)$ measurement and isoforms determination}

Assay for PKC activity. Confluent IEC6 monolayers were treated with ZOT-containing supernatants for increasing time intervals. PKC activity was determined using a PKC assay system (GIBCO BRL, Grand Island, $\mathrm{NY}$ ) based on measurement of the phosphorylation of acetylated myelin basic protein as described by Yasuda et al. (19). The net PKC activity value reflects the difference between PKC activity in the presence and absence of PKC 19-26, a PKC pseudosubstrate inhibitor (19). Total PKC specific activity ( $\mathrm{pmol} / \mathrm{min}$ ) was normalized to total protein.

Immunoblot analysis. Affinity-purified anti-PKC- $\alpha$ and $\epsilon$ antibodies (GIBCO BRL) as well as the corresponding isoform-specific peptides (GIBCO BRL) were used for immunoblotting. Amino acid sequences of the synthetic peptides for each respective PKC isoform were based on unique sequences in the $\mathrm{V}_{3}$ region of $\alpha$ (AGNKVISPSEDRRQ) and $\epsilon$ (KGFSYFGEDLMP) PKCs. For identification of PKC isoforms, cytosolic membrane fractions (15-30 $\mu \mathrm{g}$ protein/lane) were separated by $8 \%$ SDS-PAGE. Separated proteins were transferred to a nylon membrane ( $N$-Immobilon; Millipore Corp.) in a Trans-Blot Electrophoretic Transfer Cell (Bio-Rad Chemical Division). The membrane was rinsed in PBS containing $0.05 \%$ Tween 20 (PBS-T) and blocked in PBS-T containing 5\% nonfat milk for $1 \mathrm{~h}$ at room temperature. Antipeptide antibodies were diluted to obtain optimal saturating conditions (as determined by preliminary studies) in PBS-T containing $0.83 \%$ nonfat milk and incubated with the membrane for $16 \mathrm{~h}$ at $4^{\circ} \mathrm{C}$. After incubation, the membrane was first washed with 5\% nonfat milk in PBS-T (three times for $15 \mathrm{~min}$ ), then with PBS-T (one time $15 \mathrm{~min}$ ) and incubated for 2 $\mathrm{h}$ at room temperature with horseradish peroxidase. After extensive washing with $5 \%$ nonfat milk in PBS-T, immunoreactive bands were developed using enhanced chemiluminescence (Amersham Corp.).

Statistical analysis. The mean response of each experimental group was compared to its simultaneous control by two-tailed Student's $t$ test for either paired or unpaired variates. Analyses of variance were used to compare the mean responses among experimental and control groups. To analyze the cytoskeleton rearrangement in IEC6 cells, an overall $\chi^{2}$ test was run among all strains tested. After obtaining a significant $P$ value, all six pairwise comparisons were performed by Fisher's test, with 
a Bonferonni adjustment for multiple comparisons. With the reversibility experiments, a $\chi^{2}$-test for trend was run for each strain, testing for attenuation of the cytoskeletal effect during the 24-h period after withdrawal of the supernatant. Finally, to evaluate the role of phospholipase $\mathrm{C}$ in ZOT action on cytoskeleton, an overall $\chi^{2}$-test was run among the three strains and negative control. After obtaining a significant $P$ value, each of the strains was compared to the control by Fisher's test, with Bonferonni adjustment for multiple comparisons.

\section{Results}

Specific effect of ZOT on different cell lines. To establish an optimal in vitro system to study the effect of ZOT on $\mathrm{tj}$, several cell lines were screened for multiple types of ZOT responsiveness. To evaluate the effect of ZOT on tj permeability on a human cell line, postconfluent monolayers of HT29cl. 19A cells were mounted in modified Ussing chambers and changes in Rt were monitored. No significant changes of Rt were observed in monolayers ( $n=4$ for each sample tested) exposed to either of the ZOT-containing supernatants when compared to monolayers exposed to the negative control for up to $3 \mathrm{~h}$. To study the effect of ZOT on F-actin organization, IEC6 and LLC PK ${ }_{1}$ cell cultures were tested. IEC6 cells exposed to ZOTcontaining supernatants and subsequently probed with fluorescein-phalloidin for F-actin, showed significant actin reorganization (see below), while no significant changes were detected

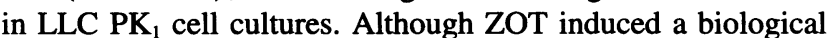
response in IEC 6 cells, their prolonged time requirements to achieve confluence made multiple quantitative measurements of the F- and G-actin pools difficult. To overcome this problem, ZOT-sensitive bovine pulmonary artery endothelial cell monolayers were employed (see below).

Effect of ZOT on F-actin organization. IEC6 cells were exposed to supernatants obtained from the strains described in Table I for varying exposure times, probed with fluoresceinphalloidin, analyzed in blind fashion, and photographed through an epifluorescence microscope. IEC6 cells exposed to ZOTcontaining supernatant ( 395 and pZ14) showed an increased percentage (peaking at 24-h incubation) of cells displaying redistribution of F-actin compared to the control-exposed cells (Fig. 1); a representative photomicrograph of this F-actin redistribution is found in Fig. $2 \mathrm{~A}$. Parallel studies performed by scanning electron microscopy showed modifications of the surface of ZOT-exposed cells when compared to the negative control, mainly consisting of loss of microvilli around the cell periphery with central sparing (Fig. $3, A$ and $B$ ). These surface changes are consistent with the time-dependent F-actin redistribution induced by ZOT.

After 48-h exposure to culture supernatants of 395 or pZ14, F-actin organization was unchanged from the cells exposed for $24 \mathrm{~h}$. F-actin organization in ZOT-negative controls remained unchanged over the 48 -h study period.

The effect of ZOT on actin rearrangement also appeared to be dose dependent. ZOT-containing supernatants diluted 1:10 and 1:30 produced the effect whereas supernatants diluted 1:50 did not. Finally, the effect of ZOT on F-actin distribution was reversible; $24 \mathrm{~h}$ after withdrawal of ZOT-positive supernatants, the actin cytoskeleton returned to its basal state (Fig. 4). These results parallel our previous observation that the ZOT effect on tissue permeability is reversible (2). The incomplete but still significant $(P<0.05)$ reversibility observed in pZ14-exposed

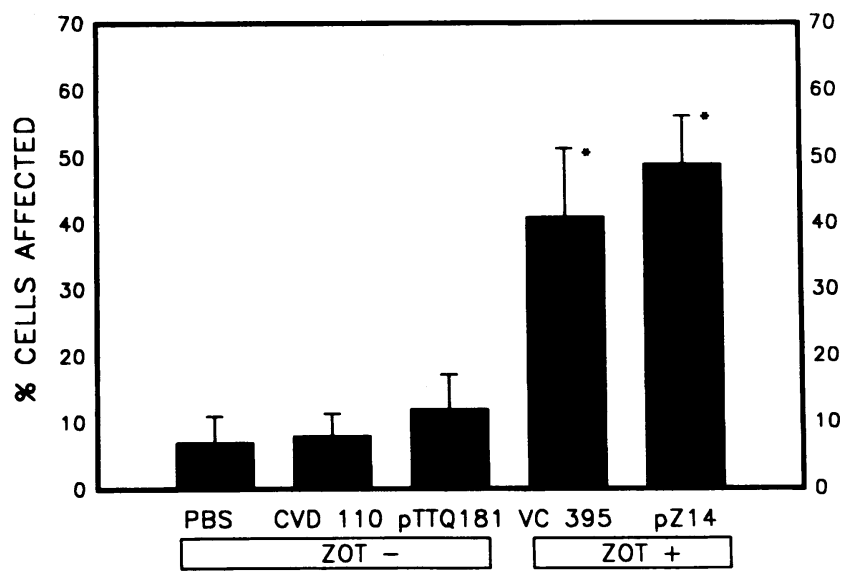

Figure 1. Effect of ZOT (+) and ZOT (-) culture supernatants on F-actin distribution in IEC6 cells. IEC6 cells were exposed to either ZOT-containing supernatants ( $V$. cholerae wild-type strain 395 and CVD110 recipient containing pZ14 plasmid) or ZOT negative strain supernatants $(V$. cholerae CVD110 recipient alone or with the plasmid vector pTTQ181). IEC6 cells exposed to PBS were used as negative control. The cells were treated for $24 \mathrm{~h}$ after which they were fixed, permeabilized, and probed with FITC-phalloidin for fluorescence microscopy studies. 200 cells were analyzed for F-actin redistribution to the cell periphery at the expense of transcytoplasmic fibers. F-actin rearrangement in each cell population was expressed as mean $( \pm \mathrm{SE})$ percent cells affected. ${ }^{*} P<0.001$ compared to ZOT $(-)$ controls.

cells may be related to the possible ZOT overexpression in this clone.

To correlate the actin rearrangement induced by ZOT with its effect on intestinal permeability, rabbit small intestine was mounted in Ussing chambers and incubated with either pZ14 or PTTQ181 supernatants. Once ZOT-exposed tissues displayed the maximal decrement of Rt (35\% decrease from the baseline Rt, compared to 5\% decrement observed in pTTQ181-treated tissue, both after 60 -min incubation), the samples were processed for $\mathrm{F}$-actin fluorescence microscopy. Tissues treated with pZ14 supernatant displayed irregular F-actin staining within the brush border, associated with a redistribution of the actin of the underlying enterocytes (Fig. $5 \mathrm{~B}$ ). These changes were more evident in the mature cells at the tip of the villi as compared to the less differentiated crypt cells (Fig. $5 B$ ). No modifications were detected in pTTQ181-exposed tissues (Fig. $5 \mathrm{~A}$ ).

Effect of ZOT on $G$ - and $F$-actin pools. Actin reorganization can involve reciprocal changes in the soluble monomeric Gand filamentous F-actin pool while the total actin pool remains unchanged. We assayed the G- and F-actin pools standardized to total cell protein in endothelial cell monolayers exposed for $24 \mathrm{~h}$ to either pTTQ181 (negative control) or pZ14 (ZOTpositive) supernatants. The results are shown in Fig. 6. ZOTcontaining supernatant induced a significant reduction of the G-actin pool and a reciprocal increase of the F-actin pool as compared to pTTQ181 negative control. This G- to F- shift is consistent with actin polymerization. This effect was completely abolished by boiling the pZ14 supernatant for $15 \mathrm{~min}$ (data not shown).

Role of phospholipase C (PLC) in ZOT activity. We evaluated the effect of PLC inhibitor neomycin sulphate on cytoskeletal reorganization induced by ZOT on IEC6 cells. Pretreatment 

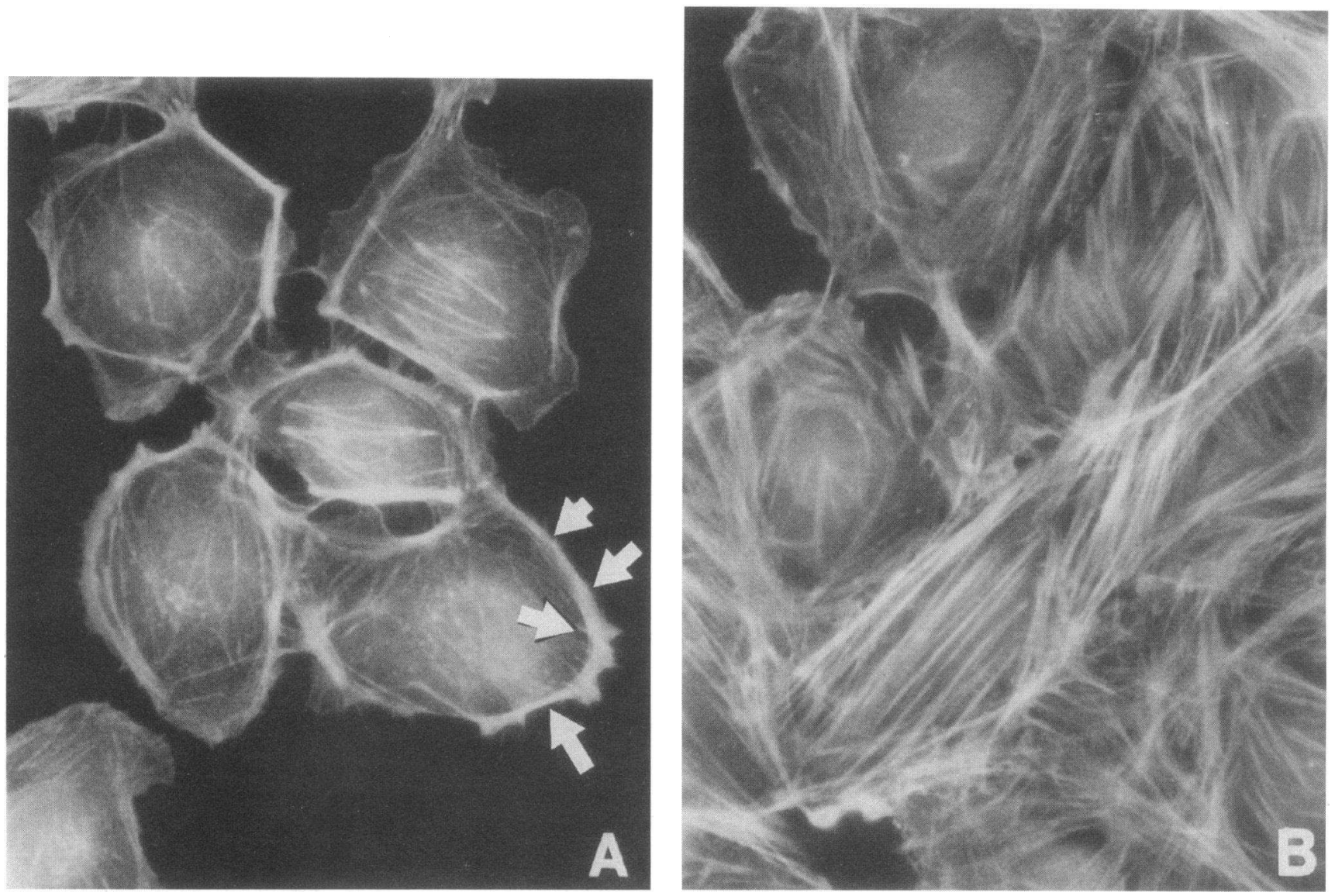

Figure 2. Fluorescence microscopy of ZOT-exposed IEC6 cells. IEC6 cells were exposed for $24 \mathrm{~h}$ to ZOT( + ) pZ14 supernatant and subsequently probed with FITC-phalloidin. $(A)$ In a significant percent of cells ZOT induced redistribution of F-actin to the subcortical compartment (see arrows in $A$ ) at the expense of transcytoplasmic microfilaments. Note normal F-actin arrangement in IEC6 cells in $B$. Magnification 630.

with $100 \mu \mathrm{M}$ neomycin sulphate prevented the cytoskeletal rearrangement induced by ZOT (Fig. 7). Preexposure of rabbit ileum to $100 \mu \mathrm{M}$ neomycin sulphate partially prevented the increased tissue permeability induced by ZOT in untreated tis- sues (Table II). These results suggest that the transmembrane PLC may play a role in ZOT-induced actin reorganization and tissue permeability.

Intracellular mediator of ZOT activity. Several intracellular
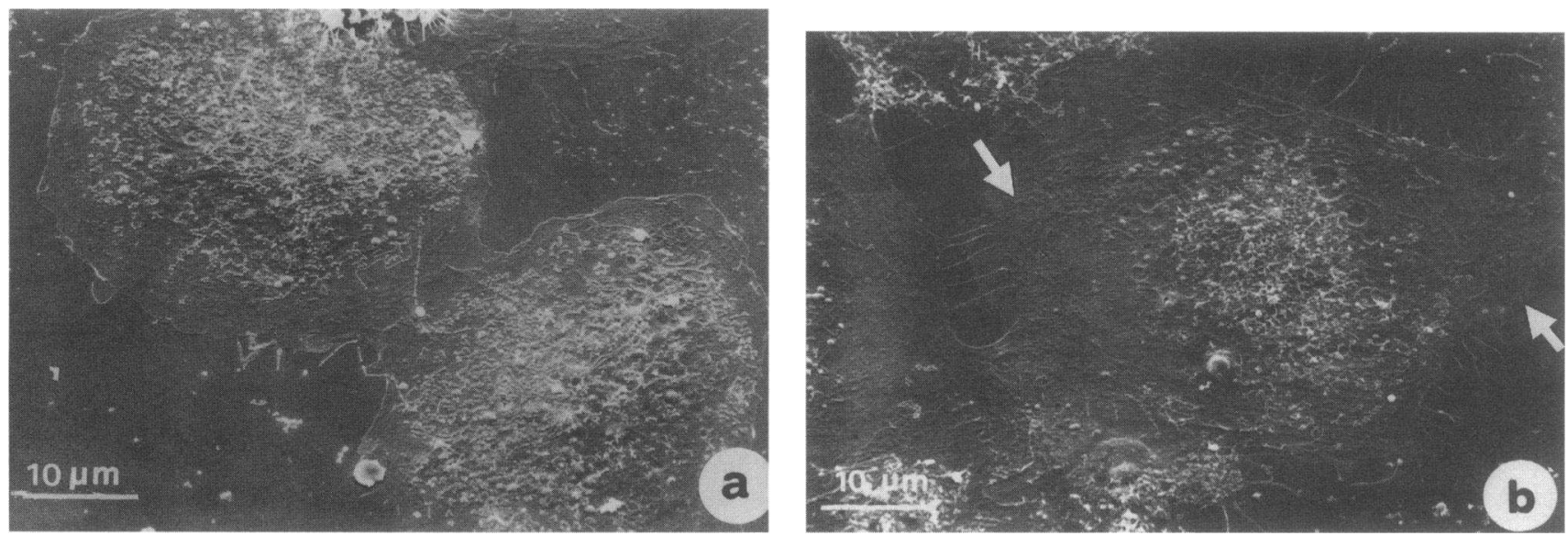

Figure 3. Scanning EM photomicrographs of ZOT-exposed and ZOT-negative control IEC6 cells. IEC6 cells were exposed for $24 \mathrm{~h}$ to $(a)$ ZOT( -$)$ pTTQ181 control supernatant or $(b)$ supernatant obtained from the isogenic, ZOT $(+)$ pZ14 strain, and studied with scanning electron microscopy. The surface microvilli on the ZOT $(-)$ control cells $(a)$ were abundant and covered the entire cell surface. The surface arrangement of ZOTexposed cells $(b)$ was profoundly altered with total loss of microvilli around the cell periphery (see arrows) with central sparing. 


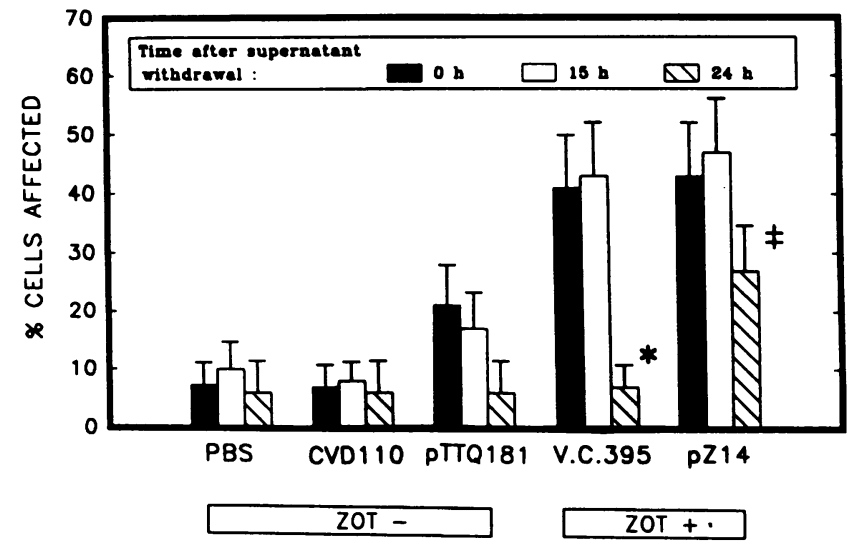

Figure 4. Reversibility of actin rearrangement induced by ZOT-containing supernatants. IEC6 cells were exposed to either ZOT $(+)$ or ZOT ( - ) supernatants for $24 \mathrm{~h}$ ( solid bars) after which the supernatants were replaced with media alone. The cells were then cultured for $15 \mathrm{~h}$ (open bars) or 24h (cross-hatched bars) and processed for F-actin fluorescence microscopy. Each bar represents the mean $\pm S E$ percent cells with F-actin rearrangement as presented in Fig. $2 A$. $^{*} P<0.001$; ${ }^{\ddagger} P<0.05$.

mediators have been mechanistically linked to changes in $\mathrm{t} j$ permeability, including CAMP, $\mathrm{Ca}^{2+}$, and PKC (5). We have previously observed that the response to theophylline in rabbit ileum preexposed to ZOT was similar to that evoked in tissues exposed to the negative control, suggesting that ZOT-induced changes in tissue permeability are not mediated through cAMP (2). As a first test of whether PKC mediates ZOT activity, rabbit small intestine was exposed to the protein kinase inhibitor staurosporine. After 5-min pretreatment with $10 \mathrm{nM}$ staurosporine, pZ14 supernatant was added to either pretreated or untreated tissues. Pretreatment with staurosporine completely abolished the expected decrement of Rt induced by ZOT (Fig. 8).

Staurosporine is a potent but nonselective inhibitor of in vitro PKC activity (20). The protein kinase inhibitory activity of the staurosporine derivative CGP41251 has increased specificity for PKC (20). We then tested the effect of CGP41251 as well as its inactive analogue CGP42700 (20), on ZOT-induced actin reorganization and tissue permeability. Actin rearrangment in ZOT-exposed IEC6 cells was completely prevented by pretreatment with $10 \mathrm{nM}$ CGP41251 but not with its inactive analogue 10 nM CGP42700 (Fig. 9). Similarly, ZOT-induced actin polymerization (i.e., decrease of G- and increase of F-actin pools) was significantly blocked when endothelial cells were pretreated with $10 \mathrm{nM}$ CGP41251, whereas pretreatment with $10 \mathrm{nM}$ CGP42700 did not protect (Table III). Finally, the reduction of Rt induced by ZOT in rabbit ileum was significantly diminished by pretreatment for 5 min with $10 \mathrm{nM}$ CGP41251 but not with $10 \mathrm{nM}$ CGP42700 (Table II). Experiments were also conducted using phorbol esters as PKC activators. TPA, when added at maximal concentrations $\left(10^{-8} \mathrm{M}\right)$ to rabbit ileal tissue, induced a significant reduction in Rt compared to the negative control $\left(-7.33 \pm 2.55\right.$ vs $-2.57 \pm 1.51 \mu \mathrm{ohms} . \mathrm{cm}^{2}, P$ $<0.005)$. When added to the same tissue, TPA together with $(\mathrm{ZOT}+)$ pZ14 supernatant produced a decrease in Rt (total Rt change: $-7.37 \pm 3.2 \mu \mathrm{ohms} . \mathrm{cm}^{2}$ ) no different than that seen with TPA alone. These combined data suggest that ZOT activates
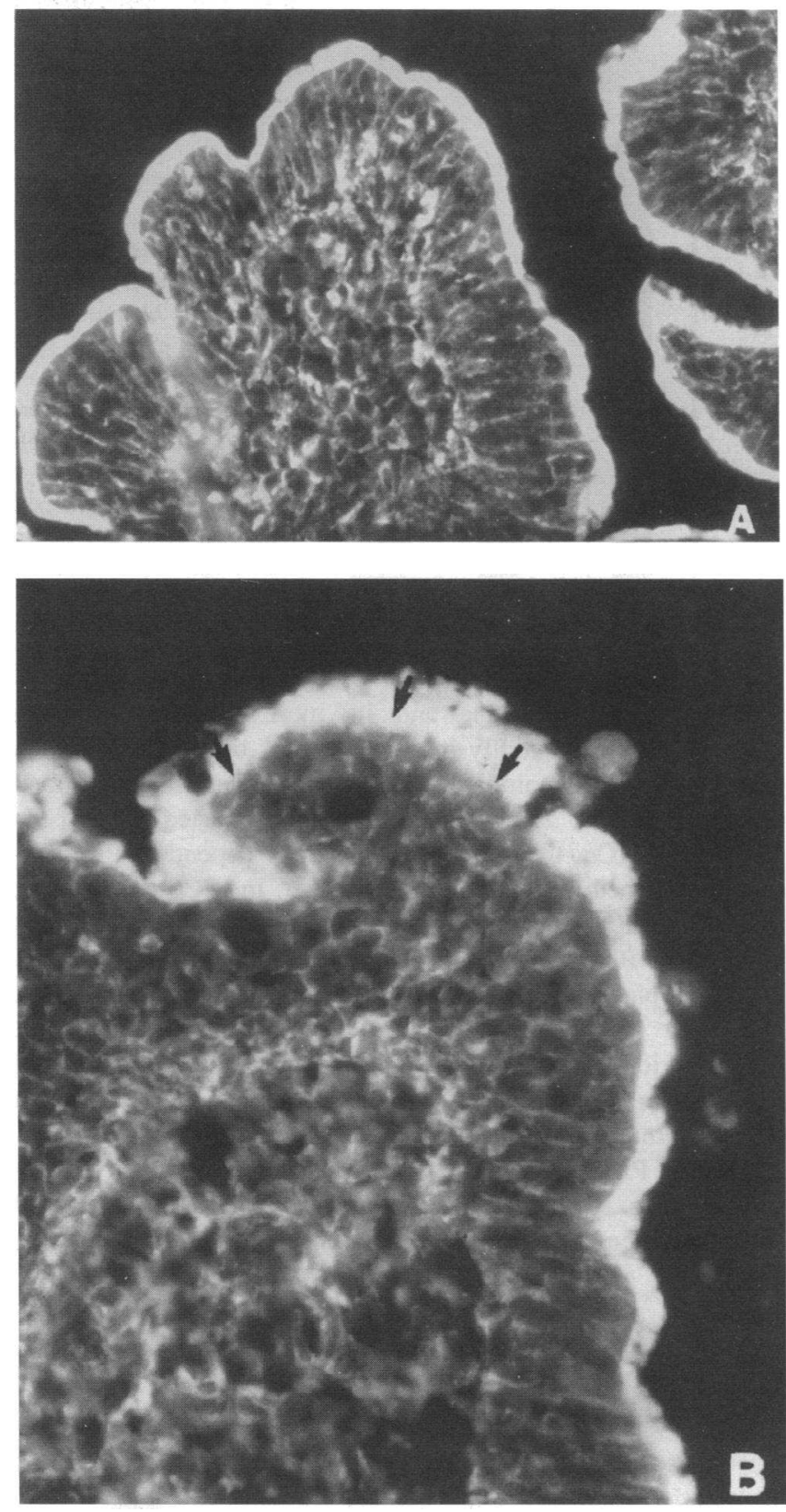

Figure 5. Cytoskeletal rearrangement in rabbit ileum. Rabbit small intestine mounted in Ussing chambers was exposed for $60 \mathrm{~min}$ to either ZOT (-) pTTQ181 or ZOT(+) pZ14 supernatants and subsequently stained for F-actin with FITC-phalloidin. $(A)$ pTTQ181-exposed tissue. Note the homogeneous staining of the brush border and the parallel staining of F-actin between adjacent enterocytes. $(B)$ pZ14-exposed tissue. Irregular F-actin staining within the brush border, associated with a redistribution of the actin of the underlying enterocytes. Note that these changes are more evident in the mature cells of the tip of the villi (arrows) as compared to the less differentiated cells along the villous axis. Magnification 100.

PKC and that this activation occurs proximally to both actin polymerization and final opening of $\mathrm{t} j$.

Molecular cloning and sequence analysis of PKC has demonstrated the existence of a gene family encoding several closely related but distinct isoforms with different physiological proper- 


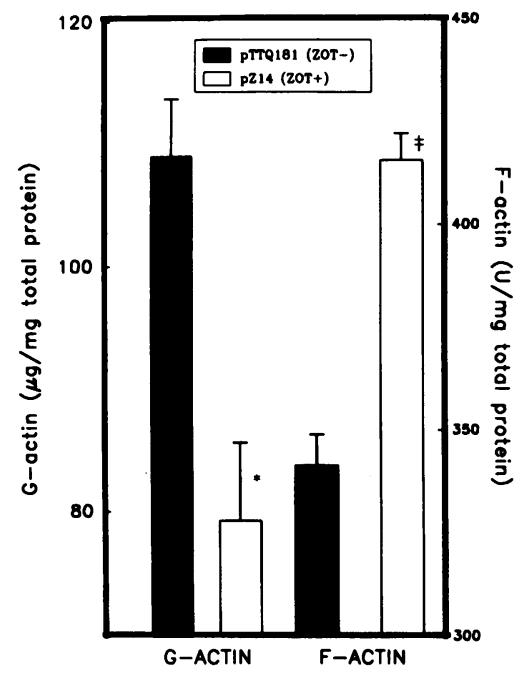

Figure 6. Effect of ZOT on the endothelial F- and G-actin pools. Endothelial monolayers were exposed for $24 \mathrm{~h}$ to either ZOT(-) pTTQ181 (solid bars) or ZOT $(+)$ pZ14 (open bars) supernatants, fixed, permeabilized, and tested for Gor F-actin. Data are expressed as mean $\pm \mathrm{SE}$ for $n=12 . * P=0.0001$ ${ }^{\ddagger} P=0.0036$.

ties (21). Staurosporine and its more specific derivative CGP41251 preferentially inhibit the $\mathrm{Ca}^{2+}$-dependent group A PKC isoforms as compared to the $\mathrm{Ca}^{2+}$-independent group B isoenzymes $(22,23)$. Consequently, we focused our experiments on PKC $\alpha$, the only detectable $\mathrm{Ca}^{2+}$-dependent PKC isoform described in ileal enterocytes (24). In IEC6 monolayers, a 3-min incubation with pZ14 supernatant decreased the expression of the PKC $\alpha$ isoform in the cytosol (Fig. 10). This reduction was partially reversed after 10-min incubation (Fig. 10). TPA $\left(10^{-7} \mathrm{M}\right.$ ) induced a similar, but more sustained (up to 2 h) reduction of cytosolic $\operatorname{PKC} \alpha$, whereas down-regulation of this isoform was observed after 24-h incubation (data not shown). Interestingly, a continuous, time-dependent accumulation of the PKC $\alpha$ regulatory subunit was observed in the cellular cytosol (Fig. 10). No significant increase in PKC $\alpha$ was detected in either membrane fractions obtained from cells exposed to

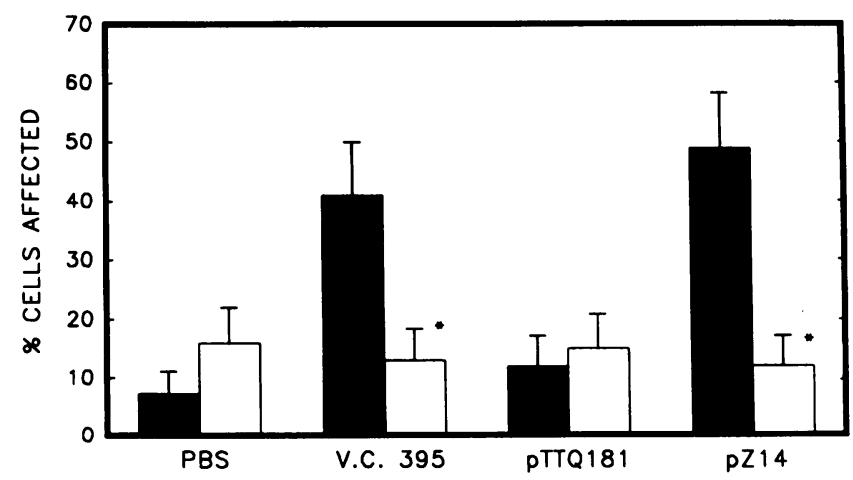

Figure 7. Effect of phospholipase $\mathrm{C}$ inhibitor neomycin sulphate on ZOT-induced cytoskeletal rearrangement in IEC6 cells. IEC6 cells were treated for $24 \mathrm{~h}$ with PBS, or culture supernatants of ZOT $(+) V$. cholerae 395 and $\mathrm{pZ14}$ or ZOT( $(-)$ pTTQ181 strains in the absence (solid bars) or presence (open bars) of neomycin sulphate $100 \mu \mathrm{M}$. ZOT-containing supernatants (either VC 395 or pZ14) induced a significant increase of the percentage of IEC6 cells showing cytoskeletal rearrangement as compared to PBS $(P<0.001)$ and pTTQ181 ( $P$ $<0.005$ ) negative controls. Pretreatment of IEC6 cell cultures with neomycin sulphate $100 \mu \mathrm{M}$ (open bars) completely abolished ZOT effect on cytoskeletal rearrangement. ${ }^{*} P<0.001$
Table II. Effect of Pharmacological Blockers on Rabbit Ileal Permeability

\begin{tabular}{lcc}
\hline \multicolumn{1}{c}{ Strain $(n)$} & Delta Rt - mohms/cm & $P$ value (vs PTTQ 181) \\
\hline pTTQ181 (7) & $-2.42(0.53)$ & \\
pZ14 (8) & $-5.75(0.41)$ & 0.0002 \\
CGP41251 + pZ14 (5) & $-3.80(0.86)$ & NS \\
CGP41251 (4) & $-3.25(1.65)$ & NS \\
CGP42700 + pZ14 (5) & $-5.40(0.81)$ & 0.01 \\
CGP42700 (3) & $-2.67(1.45)$ & NS \\
Neomycin + pZ14 (4) & $-3.96(0.89)$ & NS \\
Neomycin (4) & $-2.02(0.66)$ & NS
\end{tabular}

Values are mean (SEM) for the number of observations given in parenthesis.

ZOT-containing pZ14 supernatant or the TPA-positive control (data not shown).

PKC was then directly measured in IEC6 cell membranes exposed to ZOT-containing supernatant. ZOT induced a 1.72fold increase of mean PKC activity that peaked $3 \mathrm{~min}$ after ZOT exposure $(134.0 \mathrm{pmol} / \mathrm{min}$ per $\mathrm{mg}$ protein vs baseline value of $77.6 \mathrm{pmol} / \mathrm{min}$ per $\mathrm{mg}$ protein) and completely returned to baseline after $10 \mathrm{~min}(65.4 \mathrm{pmol} / \mathrm{min}$ per $\mathrm{mg}$ protein $)$ (average of three experiments).

\section{Discussion}

The structural composition of the zonula occludens and their regulation have been only partially characterized (9). A candidate for the transmembrane protein strands, occludin, has re-

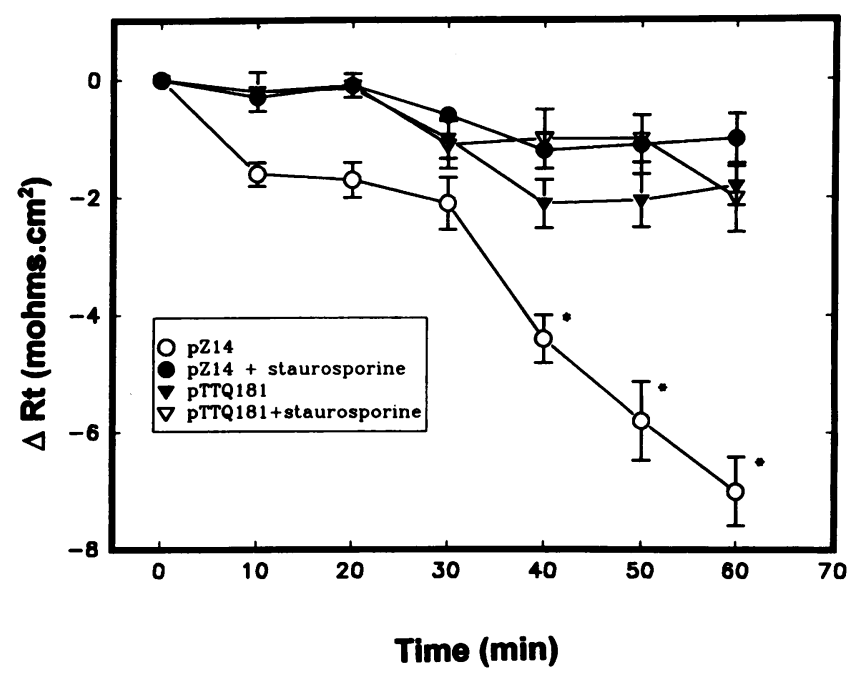

Figure 8. Time course of resistance response of rabbit ileum to ZOT with or without pretreatment with staurosporine $10 \mathrm{nM}$. The significant fall in resistance observed in tissues exposed to ZOT (+) pZ14 supernatant alone (open circles) was completely abolished by the pretreatment with staurosporine 10nM (solid circles). Tissues exposed to ZOT(-) pTTQ181 supernatant (solid triangles) or pretreated with staurosporine $10 \mathrm{nM}$ and then exposed to PTTQ181 supernatant (open triangles) showed no significant changes in Rt. $* P<0.01$ for $n=5$ animals. 


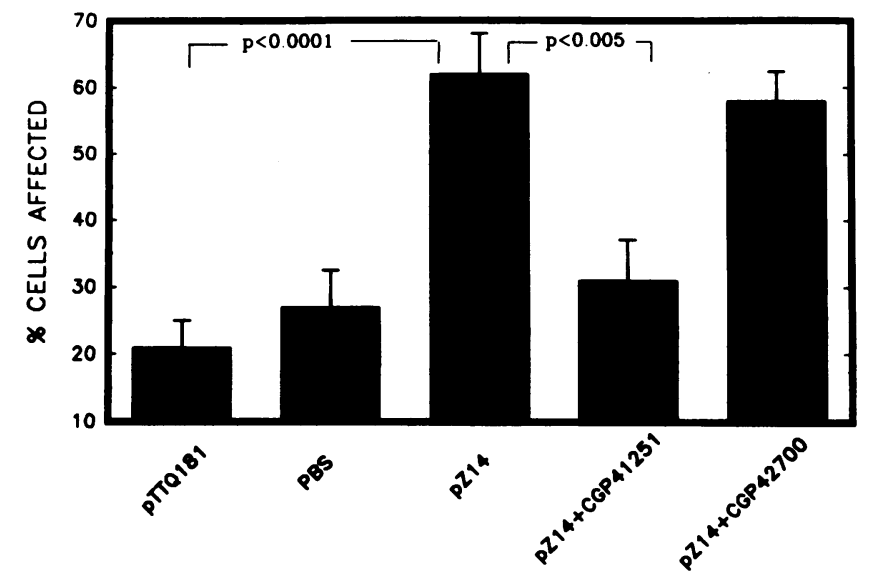

Figure 9. Effect of the specific PKC inhibitor CGP41251 and its inactive analogue CGP42700 on cytoskeletal reorganization induced by ZOT in IEC6 cells. IEC6 cells were exposed for $24 \mathrm{~h}$ to either ZOT ( + ) pZ14 or ZOT (-) pTTQ181 supernatants or PBS negative control, and then probed with FITC-phalloidin. A subset of cells were preexposed to either the PKC inhibitor CGP41251 or its inactive analogue CGP42700 $30 \mathrm{~min}$ before and throughout the pZ14 supernatant exposure. The percentage of cells presenting cytoskeletal rearrangement was significantly higher in cells exposed to pZ14 supernatant as compared to either pTTQ181 or PBS negative controls. F-actin rearrangement seen in pZ14exposed IEC6 cells was completely prevented by pretreatment with CGP41251 $10 \mathrm{nM}$ but not with its inactive analogue CGP42700 $10 \mathrm{nM}$ $(P=0.789$ compared to $\mathrm{pZ14}$-exposed cells $)$.

cently been identified ( 25 ), and six proteins have been identified in a cytoplasmic submembraneous plaque underlying membrane contacts, but their function has not been established (9). Based on the analogy with the known functions of plaque proteins in the better characterized cell junctions, focal contacts (26), and adherens junctions (27), one can hypothesize that tight junction-associated plaque proteins are involved in transducing signals in both directions across the cell membrane and in regulating links to the cortical actin cytoskeleton. There is now abundant evidence that $t j$, once regarded as static, are in fact dynamic structures that readily adapt to a variety of developmental ( 28 , 29), physiological (30-32), and pathological (33-35) circumstances. Several independent reports have been published on the structural and functional linkage between the actin cytoskeleton and the tj complex of absorptive cells (36-38), and the

Table III. Effect of PKC Inhibitor GCP 41251 on Actin Polymerization

\begin{tabular}{|c|c|c|c|c|}
\hline Strain $(n)$ & $\begin{array}{l}\text { G-actin } \mu \mathrm{g} / \mathrm{mg} \\
\text { protein }\end{array}$ & $\begin{array}{c}P \text { value } \\
\text { (vs pTTQ181) }\end{array}$ & $\begin{array}{l}\text { F-actin U/mg } \\
\text { protein }\end{array}$ & $\begin{array}{c}P \text { value } \\
\text { (vs pTTQ181) }\end{array}$ \\
\hline \multicolumn{5}{|l|}{ pTTQ181 } \\
\hline pZ14 (38) & $76.01(4.16)$ & 0.0001 & $415.73(22.03)$ & 0.0036 \\
\hline \multicolumn{5}{|l|}{ CGP41251 } \\
\hline $\begin{array}{l}+ \text { pZ14 (30) } \\
\text { CGP42700 }\end{array}$ & $108.61(7.20)^{*}$ & 0.7803 & $335.67(12.1)^{\ddagger}$ & 0.673 \\
\hline$+\mathrm{pZ} 14$ (30) & $84.78(4.05)$ & 0.0011 & 446.17 (18.5) & 0.0001 \\
\hline
\end{tabular}

Values are mean (SEM) for the number of observations given in parentheses. ${ }^{*} P$ $=0.0003$ vs pZ14; $P=0.0056$ vs $C G P 42700+\mathrm{pZ14}^{\ddagger}{ }^{\ddagger} P=0.0045$ vs $\mathrm{pZ14}$; $P=0.0002$ vs CGP42700 + pZ14.

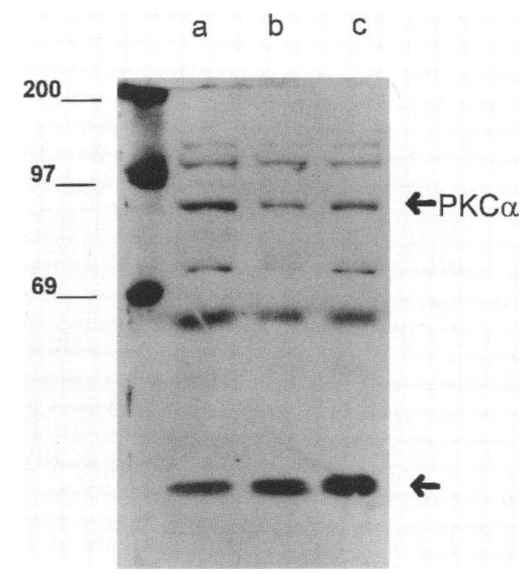

Figure 10. Immunoblots of PKC- $\alpha$ isoform in IEC6 cell cytosol with and without ZOT treatment. IEC6 cells were incubated at increasing time intervals with ZOTcontaining pZ14 supernatant and cytosol fraction prepared. Lanes are as follows: $(a)$ cytosol without treatment; $(b)$ cytosol after 3-min exposure to pZ14 supernatant; (c) cytosol after 10-min exposure to $\mathrm{pZ14}$ supernatant. PCK $\alpha$ decreases

after 3-min exposure to ZOT, suggesting activation of the isoform. Note the time-dependent increase of the regulatory subunit of the enzyme (arrow) after ZOT exposure.

possible intracellular mediators involved in the regulation of paracellular permeability (39-43). Recently, controversial data concerning the role of PKC on tj regulation have been generated. Hecht and coworkers (43) have demonstrated that prolonged exposure of T84 cell monolayers to the phorbol ester TPA induces disassembly and decreased transmonolayer resistance, related to a rearrangement of the cellular cytoskeleton. These changes were associated with down-regulation of PKC and were reversible. TPA failed to induce any significant change of the tissue resistance for the first $12 \mathrm{~h}$ of exposure. On the other hand, Stenson et al. (39) reported that treatment of $\mathrm{CaCo} 2$ cell monolayers with TPA decreases transmonolayer resistance and activates PKC. These effects were evident after treatments as brief as $30 \mathrm{~min}$ and were reversible. The discrepancy between these two papers on the role of PKC (activation or down-regulation) on tj modulation may be related to activation of different pathways eventually involved in tj modulation, or to functional differences between these two transformed cell lines. Frawley et al. have recently reported that while treatment of $\mathrm{CaCo} 2$ cells with TPA causes immediate activation of PKC, prolonged treatment with the phorbol ester down-regulates total PKC (44). These data suggest that varying exposure times with phorbol esters may have different effects on PKC expression.

Hecht et al. (43) and Stenson et al. (39) conducted their studies on tumoral cell lines, whereas we have used physiologically intact intestinal epithelium to study the role(s) of PKC activation and actin rearrangement on the paracellular pathway. We believe that our use of the intestinal mucosa "in toto," combined with the use of nontumoral cell lines (i.e., IEC6 cells, bovine endothelial cells) and the observation that ZOT displays target cell specificity, may more closely reflect PKC-dependent physiological modulation of $\mathrm{tj}$. Our data indicate that ZOT induces a short-lived reduction of cytosolic PKC $\alpha$ as detected by immunoblotting, without a concurrent detectable increase of this isoform in the membrane fraction. However, direct measurement showed a 1.72-fold increase of the PKC activity in the membrane fraction that temporally paralleled the changes seen in the cytosol with immunoblotting. These data suggest that either the amount of PKC $\alpha$ translocated to the membrane after ZOT exposure is too limited to be detected by immunoblot- 
ting, or that beside PKC $\alpha$, other PKC isoforms contribute to the increase in PKC activity. Since staurosporine also reportedly inhibits PKC $\epsilon,(45)$, we tested the effect of ZOT on this $\mathrm{Ca}^{2+}$. independent PKC isoform. No significant activation was observed in ZOT-exposed cells up to $2 \mathrm{~h}$ (Fasano, A., and S. Uzzau, unpublished observations), disputing the possible involvement of other PKC isoforms in ZOT activity. Notably, a continuous, time-dependent increase of the PKC $\alpha$ regulatory subunit in the IEC6 cell cytosol was detected after ZOT exposure (see Fig. 10). This finding may be related to the limited proteolysis of the PKC $\alpha$ at its variable region $V_{3}$, a process that seems to activate the enzyme by releasing the catalytically fully active fragment from the regulatory subunit (46). Subsequently, the catalytic subunit is rapidly removed from the cell, while the regulatory subunit accumulates in the cellular cytosol (46). These data further support the involvment of PKC $\alpha$ in ZOT-mediated ti regulation.

In the present paper we have applied an experimental design that interdependently and sequentially links some of the steps probably involved in the physiologic regulation of $t \mathrm{j}$. We have demonstrated that ZOT-containing supernatants induce doseand time-dependent rearrangment of F-actin. Experiments conducted on rabbit small intestine demonstrated that these changes are coupled to increased tissue permeability. Based on our results, we suggest that the modifications of cytoskeletal organization that lead to the opening of tj are related to the PKC $\alpha$-dependent polymerization of actin monomers into actin filaments strategically localized to regulate the paracellular pathway.

There is now a large body of evidence that protein phosphorylation plays a major role in tj development (47) and cytoskeletal rearrangement $(48,49)$. The actin cytoskeleton is composed of a complicated meshwork of microfilaments whose precise geometry is regulated by a large cadre of actin-binding proteins. One example of an actin-binding protein whose state of phosphorylation might regulate $\mathrm{F}$-actin linkage to the plasma membrane is the myristoylated alanine-rich $\mathrm{C}$ kinase substrate (MARCKS). MARCKS is a specific PKC substrate that is associated with the cytoplasmic face of the plasma membrane (50). In its nonphosphorylated form, MARCKS cross-links to the submembranous actin, so it is likely that the actin meshwork associated with the membrane via MARCKS is relatively rigid (51). Activated PKC phosphorylates MARCKS, which dissociates from the membrane $(52,53)$. The actin linked to MARCKS is likely to be spatially separated from membrane and more plastic. When MARCKS is dephosphorylated, it returns to the membrane where it once again cross-links actin $(51,53)$. Therefore, there is precedent for regulation of actin organization through a PKC-dependent phosphorylation process.

The selective sensitivity of various cell lines to ZOT, along with the observation that ZOT increases tissue permeability only in the ileum but not in the colon (2), suggest that ZOT may interact with a specific receptor, whose surface expression on various cells differs. We also noted a differential sensitivity to ZOT among the enterocytes, with the mature cells of the tip of the villi being more sensitive then the less mature crypt cells. This observation suggests that the number of ZOT receptors may decrease along the villous-crypt axis, and may also explain why the effect of ZOT on IEC6 cells (i.e., cell line derived from rat crypt cells) requires a longer exposure time compared to whole tissue.
The effect of ZOT on the cytoskeletal structure and tj permeability somewhat resembles the perturbations induced by Clostridium difficile (CD) toxin A on these cellular elements (54). However, major differences should be emphasized. ZOT exerts a reversible effect on cytoskeletal rearrangement and tissue permeability, while $\mathrm{CD}$ toxin $\mathrm{A}$ induces changes that are generally irreversible (54). ZOT action seems to be tissue-specific: it is active on epithelial cells of the small intestine and on endothelial cells, but not on colonocytes or renal epithelial cells. $\mathrm{CD}$ toxin A effect is not tissue specific (54). Moreover, ZOT is active mainly on the mucosal side (A. Fasano, unpublished results), while $C D$ toxin $A$ is active both on mucosal and serosal sides (55). According to Hecht and coworkers, CD toxin A markedly decreases F-actin staining intensity in T84 monolayers, a finding that was interpreted as a decrease in the cellular content of polymerized F-actin (55). In addition, Ottlinger et al. have reported that $\mathrm{CD}$ toxin $\mathrm{B}$ induces $\mathrm{F}$-actin depolymerization in balb/c 3T3 fibroblasts (56). As we have clearly demonstrated in the present report, ZOT decreases the G-actin pool with a reciprocal increase in the F-actin pool, thus exerting an effect on actin filaments (polymerization) that is the opposite of that expected for CD toxin A and B. Finally, CD toxin A markedly alters epithelial structure and function (glucose-elicited increase in $\mathbf{I}_{\mathrm{sc}}$ was significantly reduced after toxin exposure [57]). When exposed to CD toxin A for more then $24 \mathrm{~h}, \mathrm{~T} 84$ monolayer resistance was almost completely abolished (55). In comparison, ZOT did not induce any changes in tissue structure and viability (glucose active absorption was unaffected [2]). Moreover, the resistance of tissues exposed to ZOT never dropped more then $30-35 \%$ from baseline values, even after prolonged exposure.

These combined data suggest that $\mathrm{CD}$ toxin $\mathrm{A}$ exerts a cytopathic, pathologic effect on epithelial cells that involves the cytoskeletal structure (depolymerization) and the tj function in an irreversible manner. In contrast, ZOT seems to activate an intracellular cascade of events aimed at regulating the tij permeability, probably by mimicking the effect of physiologic modulator(s) of the epithelial barrier function. By using ZOT as a zonula occludens modulator, it may be possible to gain further insight into the physiology of $\mathrm{t} j$ regulation, particularly at the cellular and molecular level.

Alteration in intestinal $t j$ function occurs in a variety of clinical conditions affecting the gastrointestinal system, including food allergies (58), malabsorption syndromes (59), and inflammatory bowel diseases $(60,61)$. The knowledge that can eventually be acquired by studying the regulation of $t j$ may have a tremendous impact on our understanding of the pathogenesis of these diseases. It would not be surprising if the modification of the structure and function of $t \mathrm{j}$ induced by these pathological conditions would be an extension of normal physiologic regulation of $\mathrm{t} j$.

However, several questions remain unanswered: what is the role on the regulation of tissue permeability of zo-1, zo-2, and other proteins that anchor the cytoskeleton to the tj? What is the target substrate( $\mathrm{s}$ ) for PKC $\alpha$ enzymatic activity? Which is the physiologic modulator(s) of tj permeability? Experiments aimed at addressing these questions are presently in progress in our laboratory.

\section{Acknowledgments}

This paper is dedicated to the memory of my father Vincenzo.

We express our graditude to Linda Ferraro and Eduardo De Gre- 
gorio, University of Naples School of Medicine, and Alessia Fabbri, Istituto Superiore Sanitá, Rome, for dedicated technical assistance. We are additionally indebted to Michael Field, Columbia University, New York, for his helpful discussion, Terry Rogers, University of Maryland, for his valuable advise on PKC experiments, and Steven Wasserman, University of Maryland, for the statistical analysis. The PKC inhibitor CGP41251 and its inactive analogue CGP42700 were kindly supplied by Ciba Geigy, Basel, Switzerland.

This work was supported in part by the office of Research and Development, Department of Veteran Affairs, and the U.S. Army Medical Research and Development Command (Grant No. DAMD 17-91A-1004 to S. E. Goldblum), and the National Institute of Health Contract No. AI19716 to J. B. Kaper.

\section{References}

1. Levine, M. M., J. B. Kaper, D. Herrington, J. G. Morris, M. L. Clements, R. E. Black, B. Tall, and R. Hall. 1988. Volunteer studies of deletion mutants of Vibrio cholerae 01 prepared by recombinant techniques. Infect. Immun. 56:161167.

2. Fasano, A., B. Baudry, D. W. Pumplin, S. S. Wasserman, B. D. Tall, J. M. Ketley, and J. B. Kaper. 1991. Vibrio cholerae produces a second enterotoxin, which affects intestinal tight junctions. Proc. Natl. Acad. Sci. USA. 88:52425246.

3. Johnson, J. A., J. G. Morris, Jr., and J. B. Kaper. 1993. Gene encoding zonula occludens toxin (zot) does not occur independently from cholera enterotoxin genes (ctx) in Vibrio cholerae. J. Clin. Microbiol. 31/3:732-733.

4. Karasawa, T., M. Tatsuya, H. Kurazono, and G. B. Nair. 1993. Distribution of the zot (zonula occludens toxin) gene among strains of Vibrio cholerae 01 and non-01. FEMS (Fed. Eur. Microbiol. Soc.) Microbiol. Lett. 106:143-146.

5. Tschape, H. 1994. Toxigenic factors of enteritis-Salmonellae. 2nd AsianPacific Symposium on Typhoid Fever and other Salmonellosis. 47a. (Abstr.)

6. Madara, J. L. 1989. Loosening tight junctions: lessons from the intestine. J. Clin. Invest. 83:1089-1094.

7. Madara, J. L. 1990. Contributions of the paracellular pathway to secretion, absorption, and barrier function in the epithelium of the small intestine. In Textbook of Secretory Diarrhea. E. Lebenthal and M. Duffey, editors. Raven Press, Ltd. New York. 125-138.

8. Gumbiner, B. 1987. Structure, biochemistry, and assembly of epithelial tight junctions. Am. J. Physiol. (Cell Physiol.) 253:C749-C758.

9. Diamond, J. M. 1977. The epithelial junction: bridge, gate and fence. Physiologist. 20:10-18.

10. Anderson, J. M., M. S. Balda, and A. S. Fanning. 1993. The structure and regulation of tight junctions. Cell Biol. 5:772-778.

11. Schneeberger, E. E., and R. D. Lynch. 1992. Structure, function, and regulation of cellular tight junctions. Am. J. Physiol. (Lung Cell. Mol. Physiol.) 262:L647-L661.

12. Kaper, J. B., H. Lockman, M. M. Baldini, and M. M. Levine. 1984 Recombinant nontoxinogenic Vibrio cholerae strains as attenuated cholera vaccine candidates. Nature (Lond.). 308:655-658.

13. Michalski, J., J. E. Galen, A. Fasano, and J. B. Kaper. 1993. CVD 110: an attenuated Vibrio cholerae 01 ELT or live oral vaccine strain. Infect. Immun. $61: 4462-4468$.

14. Baudry, B., A. Fasano, J. Ketley, and J. B. Kaper. 1992. Cloning of a gene (zot) encoding a new toxin produced by Vibrio cholerae. Infect. Immun. 60:428-434

15. Van Den Berghe, N., A. B. Vaandrager, A. G. M. Bot, P. J. Parker, and H. R. De Jonge. 1992. Dual role of protein kinase $C$ as a regulator of ion secretion in the HT29 cl. 19A human colonic cell line. Biochem. J. 285:673-679.

16. Quaroni, A., and R. J. May. 1980. Establishment and characterization of intestinal epithelial cell cultures. In Methods in Cell Biology. Academic Press, Inc., San Diego, CA. 403-426.

17. Hull, R. N., W. R. Cherry, and G. W. Weaver. 1976. The origin and characteristics of a pig kidney cell strain, LLC-PK. In Vitro (Rockville). 12:670677.

18. Goldblum, S. E., X. Ding, T. W. Brann, and J. Campbell-Washington. 1993. Bacterial lipopolysaccharide induces actin reorganization, intercellular gap formation and endothelial barrier dysfunction in pulmunary vascular endothelial cells. Concurrent F-actin depolymerization and new actin synthesis. J. Cell. Physiol. 157:13-23.

19. Yasuda, I., A. Kishimoto, S. Tanaka, M. Tominaga, A. Sakurai, and Y. Nishizuka. 1990. A synthetic peptide substrate for selective assay of protein kinase C. Biochem. Biophys. Res. Commun. 166:1220a. (Abstr.)

20. Meyer, T., U. Regenass, D. Fabro, E. Alteri, J. Rosel, M. Muller, G. Caravatti, and A. Matter. 1989. A derivative of staurosporine (CGP 41251 ) shows selectivity for protein kinase $\mathrm{c}$ inhibition and in vitro anti-proliferative as well as in vivo anti-tumor activity. Int. J. Cancer. 43:851-856.

21. Azzai, A., D. Boscoboinik, and C. Hensey. 1992. The protein kinase C family. Eur. J. Biochem. 208:547-57.

22. McGlynn, E., J. Liebetanz, S. Reutener, J. Wood, N. B. Lydon, H. Hofstetter, M. Vanek, T. Meyer, D. Fabbro. 1992. Expression and partial characterization of rat protein kinase C-S and protein C-S in insect cells using recombinant baculovirus. J. Cell. Biochem. 49:239-250.

23. Marte, B. M., T. Meyer, S. Stabel, G. J. R. Standke, S. Jaken, D. Fabbro, and N. E. Hynes. 1994. Protein kinase $C$ and mammary cell differentiation: involvment of protein kinase $\mathrm{C} \alpha$ in the induction of $\beta$-casein expression. Cell Growth \& Differ. 5:239-247.

24. Hyun, C. S., L. A. Martello, and P. I. Karl. 1994. Identification of protein kinase $\mathrm{C}-\alpha, \epsilon$ and $\zeta$ in rabbit ileal enterocytes. Comp. Biochem. Physiol. 108(2):171-178.

25. Furuse, M., T. Hirase, M. Itoh, A. Nagafuchhi, S. Yonemura, S. Tsukita, and S. Tsukita. 1993. Occludin: a novel integral membrane protein localizing at tight junctions. J. Cell Biol. 123:1777-1788.

26. Guan, J. L., and D. Shalloway. 1992. Regulation of focal adhesion-activated protein tyrosine kinase by both cellular adhesion and onogenic transformation. Nature (Lond.). 358:690-692.

27. Tsukita, S., M. Itoh, A. Nagafuchi, S. Yonemura, and S. Tsukita. 1993. Submembranous junctional plaque proteins include potential tumor suppressor molecules. J. Cell Biol. 123:1049-1053.

28. Magnuson, T., J. B. Jacobson, and C. W. Stackpole. 1978. Relationship between intercellular permeability and junction organization in the preimplantation mouse embryo. Dev. Biol. 67:214-224.

29. Schneeberger, E. E., D. V. Walters, and R. E. Olver. 1978. Development of intercellular junctions in the pulmonary epithelium of the foetal lamb. J. Cell Sci. 32:307-324.

30. Madara, J. L., and J. R. Pappenheimer. 1987. Structural basis for physiological regulations of paracellular pathways in intestinal epithelia. J. Membr. Biol. 100:149-164.

31. Mazariegos, M. R., L. W. Tice, and A. R. Hand. 1984. Alteration of tight junctional permeability in the rat parotid gland after isoproteranol stimulation. $J$. Cell Biol. 98:1865-1877.

32. Sardet, C., M. Pisam, and J. Maetz. 1979. The surface epithelium of teleostean fish gills. Cellular and junctional adaptations of the chloride cell in relation to salt adaptation. J. Cell Biol. 80:86-117.

33. Milks, L. C., G. P. Conyers, and E. B. Cramer. 1986. The effect of neutrophil migration on epithelial permeability. J. Cell Biol. 103:2729-2738.

34. Nash, S., J. Stafford, and J. L. Madara. 1988. The selective and superoxideindependent disruption of intestinal epithelial tight junctions during leukocyte transmigration. Lab. Invest. 59:531-537.

35. Shasby, D. M., M. Winter, and S. S. Shasby. 1988. Oxidants and conductance of cultured epithelial cell monolayers: inositol phospholipid hydrolysis. Am. J. Physiol. (Cell Physiol.) 255:C781-C788.

36. Madara, J. L., D. Barenber, and S. Carlson. 1986. Effects of cytochalasin D on occluding junctions of intestinal absorptive cells: further evidence that the cytoskeleton may influence paracellular permeability and junctional charge selectivity. J. Cell Biol. 102:2125-2136.

37. Madara, J. L. 1987. Intestinal absorptive cell tight junctions are linked to cytoskeleton. Am. J. Physiol. (Cell Physiol.) 253:C171-C175.

38. Gumbiner, B., T. Lowenkopf, and D. Apatira. 1991. Identification of a $160-\mathrm{kDa}$ polypeptide that binds to the tight junction protein ZO-1. Proc. Natl. Acad. Sci. USA. 88:3460-3463.

39. Stenson, W. F., R. A. Easom, T. E. Riehl, and J. Turk. 1993. Regulation of paracellular permeability in Caco-2 cell monolayers by protein kinase C. Am. J. Physiol. (Gastrointest. Liver Physiol.) 265:G955-G962.

40. Bakker, R., and J. A. Groot. 1984. cAMP-mediated effects of ouabain and theophylline on paracellular ion selectivity. Am. J. Physiol. 246:G213-G217.

41. Palant, C. E., M. E. Duffey, B. K. Mookerjee, S. Mo, and C. J. Bentzel. 1983. $\mathrm{Ca}^{2+}$ regulation of tight junction permeability and structure in Necturus gallbladder. Am. J. Physiol. 245:C203-C212.

42. Ellis, B., E. E. Schneeberger, and C. A. Rabito. 1992. Cellular variability in the development of tight junctions after activation of protein kinase C. Am. J. Physiol. (Renal Fluid Electrolyte Physiol.) 203:F293-F300.

43. Hecht, G., B. Robinson, A. Koutsouris. 1994. Reversible disassembly of an intestinal epithelial monolayer by prolonged exposure to phorbol ester. Am. J. Physiol. (Gastrointest. Liver Physiol.). 266:G214-G221.

44. Frawley, B. P., Jr., X. Y. Tien, S. C. Hartmann, R. K. Wali, S. M Niedziela, N. O. Davidson, M. D. Sitrin, T. A. Brasitus, and M. Bissonnette. 1994. TPA causes divergent responses of $\mathrm{Ca}^{2+}$-dependent and $\mathrm{Ca}^{2+}$-independent isoforms of PKC in the nuclei of CaCo-2 cells. Biochim. Biophys. Acta 1222:301 305.

45. Schaap, D. and P. J. Parker. 1990. Expression, purification, and characterization of protein kinase C- $\epsilon$. J. Biol. Chem. 265:7301-7307. 
46. Mikawa, K. 1990. Studies on proteolysis of protein kinase $C$ with calpain I and II. Kobe J. Med. Sci. 36:55-69.

47. Nigam, S. K., N. Denisenko, E. Rodriguez-Boulan, and S. Citi. 1991. The role of phosphorylation in development of tight junctions in cultured renal epithelial (MDCK) cells. Biochem. Biophys. Res. Commun. 181:548-553.

48. Furuhashi, K., and S. Hatano. 1990. Control of actin filament length by phosphorylation of fragmin-actin complex. J. Cell Biol. 111:1081-1087.

49. Tang, D. G., J. Timar, I. M. Grossi, C. Renaud, V. A. Kimler, C. A. Diglio, J. D. Tylor, and K. V. Honn. 1993. The lipoxygenase metabolite, 12(SOHETE), induces a protein kinase C-dependent cytoskeletal rearrangement and retraction of microvascular endothelial cells. Exp. Cell Res. 207:361-375.

50. Aderem, A. 1992. Signal transduction and the actin cytoskeleton: the roles of MARCKS and profilin. TIBS (Trends Biochem. Sci.) 17:438-443.

51. Hartwig, J. H., M. Thelen, A. Rosen, P. A. Janmey, A. C. Nairn, and A. Aderem. 1992. MARCKS is an actin filament cross linking protein regulated by protein kinase $\mathrm{C}$ and calcium-calmodulin. Nature (Lond.). 356:618-622.

52. Rosen, A., K. F. Keenan, M. Thelen, A. G. Nairn, and A. Aderem. 1990. Activation of protein kinase $C$ results in the displacement of its myristoylated, alanine-rich substrate from punctate structure in macrophage filopodia. J. Exp. Med. 172:1211-1215.

53. Thelen, M., A. Rosen, A. C. Naim, and A. Aderem. 1991. Regulation by phosphorylation of reversible association of a myristoylated protein kinase C substrate with the plasma membrane. Nature (Lond.). 351:320-322.
54. Fiorentini, C., and M. Thelestam. 1991. Clostridium difficile toxin A and its effects on cells. Toxicon. 29:543-567.

55. Hecht, G., C. Pothoulakis, J. T. LaMont, and J. L. Madara. 1988. Clostridium difficile toxin A pertubs cytoskeletal structure and tight junction permeability of cultured human intestinal epithelial monolayers. $J$. Clin Invest. 82:1516-1524. 56. Ottlinger, M. E., and S. Lin. 1988. Clostridium difficile toxin B induces reorganization of actin, vinculin, and talin in cultured cells. Exp. Cell Res. 174:215-229.

57. Moore, R., C. Pothoulakis, J. T. LaMont, S. Carlson, and J. L. Madara. 1990. Clostridium difficile toxin A increases intestinal permeability and induces $\mathrm{Cl}^{-}$secretion. Am. J. Physiol. (Gastrointest. Liver Physiol.) 259:G165-G172.

58. Paganelli, R., R. J. Levinsky, J. Brostoff, and D. G. Wraith. 1979. Immune complexes containing food proteins in normal and atopic subjects after oral challenge and effect of sodium cromoglycate on antigen absorption. Lancet. i:12701272.

59. Bjarnason, I., T. J. Peters, and N. Veall. 1983. A persistent defect in intestinal permeability in coeliac disease demonstrated by a ${ }^{51} \mathrm{Cr}$-labelled EDTA absorption test. Lancet i:323-325.

60. Pearson, A. D., E. J. Eastham, M. F. Laker, A. W. Craft, and R. Nelson. 1982. Intestinal permeability in children with Crohn's disease and coeliac disease. Br. Med. J. ii:219-221.

61. Hollander, D. 1988. Crohn's disease: a permeability disorder of the tight junction. Gut. 29:1621-1624. 